DOI: 10.1515/ausp-2016-0009

\title{
At the Intersection of Identities
}

\author{
Judit HIDASI \\ Budapest Business School (Hungary) \\ Department of Social Communication and Media Studies \\ hidasi.judit@uni-bge.hu
}

\begin{abstract}
It is assumed that part of today's societal difficulties, uncertainties and crisis worldwide can be attributed to the competing of multiple identities, to their intersections and their overlapping nature - on the level of nations, on the level of communities and also on the level of the individual. We aim at presenting a typology of identities that come into play in the public and in the private domain of the individual. It is hypothesized that there is a strong interdependence of cultural heritage, human values and social traditions in the competition of identities. These questions, which are interrelated and interconnected with each other through a common denominator, namely "cultural-mental programming" and "reprogramming efforts," are going to be pondered about in the presentation. In the context of globalization the relevance of this topic is reinforced by the need to adapt to changes within the ever-intensifying shift from intercultural to multicultural environment in communities, in business and in work places. Attempts will be made to articulate some projections with respect to future trends that are to be expected: the way to go from competing identities to establishing a competitive identity (Simon Anholt). The contribution does not offer ready solutions but rather serves as fuel for further discussions.
\end{abstract}

Keywords: multiple identities, cultural-mental programming, competing identities, competitive identity.

Mammals require three essentials in life, identity, stimulation, and security, and by far the most important of these three psychological cornerstones is identity. (David Sheldrick 1919-1977)

\section{Our Identities}

Social psychologists have been engaged in the study of identity and the individuals' self-identification for almost fifty years. It suffices to refer, in this regard, to the works by world-renowned scientist George Mead (1934). In fact, all of us carry several identities: gender and racial identities are innate (biologically 
determined) properties. And we might well believe that such identities constitute constant and unchangeable attributes. Yet, experience attests that different ages and different societies recognize, accept and tolerate such issues in diverse ways and that societies relate differently to the legal, social, moral and technical conditions associated with self-initiated changes in the above attributes. On the other hand, it is also noteworthy that different societies likewise judge and control these issues in diverse ways. Let us consider Michael Jackson's desperate attempts to undergo operations through which he wished to approximate his image to that of an ideal "white rockstar." A similarly debated and widelynegotiated issue is the one currently on the table in Sweden: the individual can and will determine his/her gender identity. Accordingly, visa application forms, apart from the two traditional gender categories of "male" and "female," also contain a third option called "undefined."

In addition to the above, another set of identities is constituted either by features we are born with or features in which we are socialized: these make up social identity, including e.g. ethnic, national, religious and class identity. This identity means belonging to a specific social group. At the same time, however, it must be noted that the approval to satisfy demands either for the acceptance or for the change of such social group membership is similarly highly dependent on both the society and the culture concerned. Such is the case of the Indian caste system, which had been sanctioning vertical social mobility for long-long centuries. As opposed to this, North American societies and public thinking celebrate vertical social mobility and deem it a virtue, which is well-reflected by the ideal of the "self-made man."

Ultimately, a great majority of our identities are acquired identities, which result partly from our professional relationships (job-related) and partly from our human relationships (family and friend roles and relationships). In a lucky scenario, the individual has a greater say in matters of acquired identities, even though some societies and cultures may actually restrict the opportunities and the rights of individuals to do so. We could mention here the institution of arranged marriage, which has been flourishing in numerous cultures (e.g. in Indian, Japanese, some Arabic and African societies).

As a consequence of the above, all of us live and exist at the focal points of the intersections of identities and this is true even if the effects as well as the deepness and strength of the impact of such identities may vary from time to time, from age to age, from place to place and from situation to situation. Thus, one of the identities of a person may temporarily become stronger and may actually overwrite any task associated with any other of his/her identities (for example, motherhood may push into the background all other identities for a while). However, with changes in life, the sequencing of these identities and the priorities associated with them may easily alter. Out of the above three types of 
identities (biological, social and acquired), the present essay wishes to discuss and focus on social identity.

\section{Changes in Social Identity}

As we see it, in today's world the importance of the issue of social identities has greatly intensified and has shifted into the centre of the narratives of not only political and public life but also of everyday life. With respect to the world surrounding us as well as the different walks of life, lifestyles, objects and behavioural patterns in it, these days we perceive and witness two unique worldwide tendencies. One of these tendencies points towards unity, whereas the other towards its opposite, i.e. diversity (Hidasi 2008b). On the one hand, what we experience is that in the developed world people more or less dress in the same way, young people mostly listen to the same songs, and surround themselves with very similar objects, let such objects be smart phones, portable players or any other novelties. At the same time, we can also observe that bigger towns offer an unprecedented range of culinary delights and we can similarly experience that workplaces and residential areas are increasingly becoming more and more multicultural (Berger and Huntington 2003). The first tendency of unification is generally attributed to globalization (Lewis 2001), while the second tendency can be connected to the process of diversification. In other words, multiculturalism is perceptibly present in all countries of the world thanks to the intensification of both mobility and migration (Hidasi 2011). Irrespective of the fact whether multiculturalism in a given country, community or region is a temporary or a permanent state, challenges related to interculturalism will surface in all likelihood (Hidasi 2008a). Among groups of diverse cultural backgrounds, workplace communities, residential area communities and the individuals themselves who constitute these communities, conflicts in value systems relating to the formation of opinions about healthcare and educational services or to residential and living conditions are likely to evolve (Huntington and Harrison 2000). Difficulties caused by communication about these issues are also prone to appear even if the people involved in such discussions communicate about these topics using the same language (Földes 2007). Studying and possessing intercultural knowledge and skills have traditionally been prescribed as expectations for newcomers, i.e. those who wish to enter a new culture. Nevertheless, growing multiculturalism and its rising intensity force us to realize that recipient cultures are also compelled to take steps towards a more expedient use and application of intercultural knowledge. This tendency is visible not only in Europe but also in the United States, where social researchers have been voicing their concerns to this end for several decades (Huntington 2005). 
Within the organizational structure of the European Union, integration (and let us bear in mind that former successful European examples of integration include, among others, the construct of state of the Austro-Hungarian Monarchy) has gained ground at a per-defined pace and in line with an already defined scenario set by the EU in the area of commerce, in the application of levies, in economy, in finances, in defence and safety as well as in politics: indeed, integration appears to be increasingly prevalent in all fields ranging from monetary policy to law-making. As opposed to this, in two fields, namely in culture and language, efforts aimed at diversification are also apparent besides and parallel to efforts of integration. Among others, Borgulya (2006) points out that, in a unique manner, Europe's cultural and linguistic realities are concurrently shaped by two, in some way opposing, effects: diversification and globalization. While diversification is connected to internationalization and refers to the fact that apart from a given nation's or country's culture other nations' or countries' cultures should likewise be present in a geographical area, globalization exhibits a countertendency and denotes unification on a global scale.

On a social level, this very process of unification and homogenization (to some extent) may in fact lead to the distortion of social consciousness: the dilemmas of “who am I?" and "who are we?" surface, and ultimately an anxiety caused by the potential loss of identity may be formed both on the level of the individual and at the level of the larger community.

As European citizens, we all experience that the process of European integration, which extends to numerous areas of life, exhibits a "glass ceiling": this glass ceiling halts all those efforts that would aim at a meaningful integration of languages and cultures. This is so as language and culture constitute particular areas the "surrendering” of which would, in social consciousness, mean the loss of a shared national and cultural identity. This fear surfaces in those reactions that are visible in the form of European attempts of the past two-three decades targeted to achieve cultural and linguistic renewal. Extending to a number of areas and genres such as dance, applied arts, culinary culture, language use, religious movements, etc., numerous countries and regions (including the Netherlands, the United Kingdom, the Baltic states, the Balkans, Transylvania and Hungary, Slovakia and the Czech Republic, etc.) boast of initiatives aiming at the renewal and popularization of conventional, local and ethnic customs, traditions and other one-of-a-kind characteristic features (Hidasi 2008b). It is no accident, either, that there seems to be a Europe-wide demand for building "country images": some countries in fact allocate considerable funds for this purpose in their budgets (Anholt 2007). In the scope these initiatives, the need to "be different" from others not only increases the given country's economic and touristic appeal but also serves as a means of reinforcing national identity and national self-identity. As a matter of fact, in all contexts such actions are necessitated by social consciousness, which undergoes 
more and more extensive homogenization. In fact, the appearance and quickly rising popularity of the Hungarian concept of "hungaricum" is also classifiable as a phenomenon of this kind.

\section{Multiculturalism in Europe in the Twenty-First Century}

In a de jure sense - and with the active support of the European Council and the European Union -, the observance of the principle of "may as many as a thousand native tongues be used and may as many as a thousand cultures be cultivated" is not hindered by any legal obstacles and in fact a certain portion of public funds is allocated to this purpose. Thanks to this, the Welsh nation, for example, by way of following a very conscious language policy, could revive their almost dead Celtic language only within a few decades and the young generation has become an active user of the ancient Welsh language. The Frisian languages have likewise been awakened from their deep sleep and as a result of the activities of some enthusiastic activists and language cultivators they have by now acquired a much more active role in Dutch cultural life than they used to assume twenty or thirty years ago. Nevertheless, apart from a few similar positive examples, it can still be generalized that, in a de facto manner, linguistic globalization is taking place right in front of our eyes. The expansion and the gaining ground of the English language are a clear example of a cause and effect relationship: globalization causes English to spread, and the spread of the English language reinforces globalization. Put differently, the English language constitutes both the result and the means of the same process, notably that of globalization. At the same time, it must also be noted that knowing a mutually understood language does not necessarily mean knowledge of some commonly used terminology or shared rules of communication. The imperative of "speaking the same language" and "using the same language" is especially markedly present in multicultural and multilingual Europe (Falkné-Bánó 2001).

The successful management and handling of multiculturalism (i.e. peaceful co-existence and collaboration) pose challenges both to those who wish to enter a given country and to those who receive such people in their country (Herm 2008). The greater the cultural distance (i.e. the national, ethnic, religious and linguistic distance) between the receiving society and the members of the migrating groups is, the more likely it is that such challenges will be present in increasingly marked ways and that they will constitute a source of conflict more and more often. From the point of view of identity, the situation of migrants is extraordinarily difficult: they feel they are second-rate citizens both in numerous ways and in a number of walks of life. They feel this way because it is not only their national identity that is pushed into the background, the fear 
of which potential loss keeps haunting them, but, in addition, they also have to face the fact that they usually end up being offered positions below the ones they previously filled in their native country. An internal medical specialist who formerly worked as a head physician will end up in the position of a consultant; a teacher formerly employed by a secondary school will hold a job as a daycare teacher; while a person who worked as a software developer engineer in his homeland will find himself in the position of a technician. And, on top of all this, all these professionals belong to that very group of migrants who have actually found a job in their area of expertise. The majority of immigrants are actually forced (possibly only initially or only temporarily) to give up their professional identities in order to be able to earn a living. They will also have to make do with a job whose status is below their levels of qualification or former position: that is the way child psychologists end up working as waitresses, teachers as taxi drivers and agricultural engineers as security guards. From the perspective of self-definition and self-identity, this group of people is certainly made frustrated and disadvantaged by having to undergo these experiences. Yet, many seem to undertake these kinds of defenceless situations in their lives in spite of all difficulties this may involve: they do so partly in the hope that sooner or later their social acceptance will increase and partly because they suppose they will be able to create better and more advantageous living conditions for their children.

From the 2010s, Europe has been seeing the intensification of debates, problems and conflicts connected to political or economic refugees, or to people wishing to settle down in the hope of a better life (Hidasi 2011). These debates, problems and conflicts are due primarily to two reasons: on the one hand, to the number of migrants arriving in the receiving countries, which ultimately seems to have exceeded the number of immigrants manageable by the countries concerned. On the other hand, the second reason is that the proportion of nonindigenous migrants has also increased, thereby posing a cultural challenge to the receiving societies concerned, which seem to have been unprepared to tackle this issue. In the originally multicultural Europe, diversification appears to further intensify and the influx of non-indigenous migrants is expected and prognosticated to cause significant changes in the composition of the population (Herm 2008; S. Kriszt and Hidasi 2010; Hidasi 2009). In fact, no viable scenarios have been prepared to address the ways the effective cultural and civilizational integration of these groups can be realized. Furthermore, the societies of the receiving countries are rightfully astonished to witness and recognize repeated instances of vandalism and acts of terrorism in their homelands. Typically, the perpetrators of such acts are not first-generation migrants but the children or grandchildren of such persons. From a social psychological perspective, this is explained by the fact that first-generation migrants do their best to settle down and establish an existence for themselves in the new environment: all 
their efforts and energy are channelled into their daily struggle to achieve successful social integration and to earn a decent living. Second and thirdgeneration people, however, are not focused on existential problems any longer but on issues related to experiencing and defining their own identities. It is my conviction that identity crises of this kind are responsible for the great majority of violent acts. In addition, it is also true to say that no patterns of processing or channelling this second and third-generation experience have been established or have been introduced. The leaders of the countries concerned and experts of this field are also trying hard to devise some solutions; these efforts, however, have not proved successful so far. For example, in 2010 in France, at the initiation of the Minister of Immigration and National Identity Eric Besson (it is also telling that it was necessary to establish such a ministry) organized nationwide discussions and debates about national identity. These events were coordinated by praefecturates and were attended by local politicians, religious leaders, diverse associations and clubs, teachers, students, parents, trade unions and companies. The questions addressed included the following: is the wearing of the Muslim burqa, which covers the entire female body, compatible with French national values?; what does it mean to be French in today's society at all? The then French government also suggested discussing questions such as making it compulsory for young people to sing the national anthem once or twice a year; the ways immigration has contributed to French national identity; and possible ways of integrating people coming from former French colonies.

\section{Tendencies and Perspectives}

Diversity and internationalization not only generate need for identity building and identity preservation but they also cause quality improvements in other areas of life. The appearance of previously unknown claims for quality as well as never-before-seen and ever-increasing expectations for good quality constitute one of the advantages of the process of internationalization. In fact, diversity is indispensable for achieving better quality. There is not one single leading football club in the world with football players coming from the same country: each club tries to "buy" and contract the best players thereby assuring high quality game. Likewise, good orchestras are also heterogeneous as far as the nationality of their musicians are concerned: these orchestras can come up to internationally good standards only if they invite "the best" musicians of the world. Similarly, affluent universities "buy" and contract the best professors from all over the world thus offering the best possible quality education in their institutions. Nevertheless, in order to introduce new quality in sports, in arts or in sciences, i.e. to be able to respond to challenges of innovation, a selection from among the pool of diversity 
must be made and the best professionals must be hired. This increased demand for quality and innovation can only be satisfied on condition mobility gets introduced in the system concerned.

At the same time, the importance of educating people about intercultural knowledge and sharing this knowledge with the most extensive possible audiences through the media and different channels of the education system must definitely be recognized and consequently exploited. As opposed to former approaches, when intercultural communication was treated as a general and broad subject, these days intercultural studies tends to increasingly become purpose-oriented and functional in curricula. At numerous universities in the world, new intercultural courses are being introduced including "intercultural communication in patient care" (the relationships between patients and caregivers and between doctors and patients differ from culture to culture and are characterized by different expectations, fears, customs, therapeutic regimes, etc.), "intercultural communication and criminology" (cultural differences, norms and people's judgements widely vary concerning the nature and motives of crime, the means of criminal investigations, the methods and ways of law enforcement as well as the different methods and ways of repentance and penance), "intercultural communication and the global environment" (in certain cultures, it is possible to hunt for whales, whereas in other cultures the same act causes a public outcry; one culture consents to making changes in the natural environment including the construction of huge dams or concrete river beds, in other cultures this is disapproved of; one culture distributes genetically modified products in consumer markets, while other cultures support biological cultivation, etc.) or "intercultural communication and family planning" (certain cultures support human intervention in physiological processes - see for example debates about the status of abortion in different countries or the Chinese one-child policy -, whereas other cultures deem the same unacceptable; in one culture it is the mother's ethnicity that is decisive in terms of the child's ethnic affiliation, while in other cultures it is the father's affiliation that counts; etc.). The introduction of these new courses signals that knowledge provided under the umbrella term "intercultural communication" has become necessary in an increasing number of fields and in very diverse walks of life. And thus the question rightly arises: could it be the case that previously there was no healthcare, there was no crime prevention, there was no environmental protection and there was no family planning? The answer to these questions is certainly 'no': all of these fields existed also formerly but they were not explored in an intercultural context. By now, due to the often-referenced globalization, even those issues have an international relevance that are related, for example, to any of the following acts: the killing of whales in the Southern Seas, the flooding of the world's food markets by genetically manipulated foods and also the failure to observe and 
control drug trafficking routes with the help of international co-operation. In fact, these days, as a result of ever-intensifying migration, we can also witness internationalization in the fields of legal interest representation and healthcare service provision (according to some witnesses, the most effective language to use with today's personnel at London-based emergency departments is Russian as the majority of the staff are from the Ukraine, the Baltic countries and Poland; at Tokyo-based clinics nurses from the Philippines can soothe Japanese patients only by using smiles as these caregivers do not speak the local language and they are supposed to communicate somehow even in that case; in Swedish hospitals a system of volunteer interpreters has been set up to help immigrants as it is really important for non-Swedish-speaking mothers to understand doctors' instructions when they have to care for their sick children). And the list concerning such internationalization is really endless (Kováts 2009).

If in the same living space people with different cultural backgrounds live together, let this co-existence be the result of their own will or be caused by some kind of coercion, then misunderstandings, frictions and conflicts arising both from differences in cultural values and the divergent assessment and evaluation of such values will be experienced on a daily basis. It is in the interest of all parties concerned, may they be migrants, immigrants or members of the receiving culture, that multiculturalism should be treated as an opportunity for synergy rather than a source of conflict (Avramov 2008). In the field of European Union level politics, Europe has been treating migration as a key issue, thereby recognizing that migration constitutes an inevitable tendency from the point of view of employment. For this reason, the intensification of mobility to this end is one of the top priorities of the EU's 2020 economic growth strategy. As a conclusion, I argue that in our era of unification and diversification, efforts must be targeted at ensuring and strengthening identity in people's consciousness both at the level of nations and individuals. One way to promote this is to preserve and guarantee multicultural diversity by legal instruments. Inevitably, for the promotion of multicultural diversity, necessary means, resources and funds must be allocated at the EU's community, national and small community levels. In my understanding, this is the price we have to pay if we wish to co-exist peacefully, prosperously and constructively. 


\section{Works Cited}

Anholt, Simon. 2007. Competitive Identity: A New Model for the Brand Management of Nations, Cities and Regions. London: Palgrave Macmillan.

Avramov, Dragana, ed. 2008. Acceptance of Immigrants in Europe? Viewpoints about Immigration and Expectations towards Foreigners in the Czech Republic, Germany, Estonia, Hungary, Austria, Poland, Slovenia and Finland. Berlin: Pro BUSINESS.

Berger, Peter L. and Samuel P. Huntington. 2003. Many Globalizations: Cultural Diversity in the Contemporary World. Oxford: Oxford University Press.

Borgulya, Ágnes. 2006. “Az európai egység kulturális sokszínúsége az értékrendek és a kultúraközi kommunikáció kutatása szemszögéből.” [“Cultural Diversity of the European Unity Looked at from the Research Stand-point on Value Systems and Intercultural Communication.] In A prioritások és a konvergencia kölcsönhatása a magyar gazdaságban. Tudományos Évkönyv [The Interaction of Priorities and Convergence in Hungarian Economy. Scientific Yearbook], ed. Pál Majoros, 265-278. Budapest: BGF.

Falkné Bánó, Klára. 2001. Kultúraközi kommunikáció. [Intercultural Communication.] Budapest: Püski Kiadó.

Földes, Csaba. 2007. "'Interkulturális kommunikáció’: koncepciók, módszerek, kérdőjelek.” [“'Intercultural Communication': Concepts, Methods and Question-marks.”] Fordítástudomány vol. IX no. 1: 14-39.

Herm, Anne. 2008. Recent Migration Trends: Citizens of EU-27 Member States Become Ever More Mobile while EU Remains Attractive to Non-EU Citizens. Statistics in Focus. Eurostat, 98/2008.

Hidasi, Judit. 2008a. Interkulturális Kommunikáció. [Intercultural Communication.] (2 $2^{\text {nd }}$ ed.) Budapest: Scolar.

Hidasi, Judit. 2008b. "Közeledés vagy távolodás? Globalizáció és multikulturalizmus az Európai Unióban." ["Convergence or Divergence? Globalization and Multiculturalism within the EU."] In A magyar mint európai és világnyelv: A XVIII. Magyar Alkalmazott Nyelvészeti Kongresszus elöadásai [Hungarian as European and World Language: Proceedings of the 18th Congress of Hungarian Applied Linguistics], vol. 5/1, ed. Orsolya Nádor, 301-304. Budapest: Balassi Intézet.

Hidasi, Judit. 2009. "Current Issues of Migration and Multiculturalism in Europe." In Global and International Migration - Realities of Labor Movements and International Marriages. Proceedings of the IFSSO XVIII. General Conference. (@Chiangmai, 2009. november 21-23.), ed. Nestor T. Castro, 25-32. Quezon City: University of the Philippines Diliman. 
Hidasi, Judit. 2011. "Mobilitás és migráció.” ["Mobilty and Migration."] In Tanulmányok a nemzetközi migráció köréból [Studies on International Migration], ed. László Nyusztay, 44-55. Budapest: Perfekt.

Huntington, Samuel P. 2005. Who Are We? The Challenges to America's National Identity. New York: Simon and Schuster.

Huntington, Samuel P. \& Harrison Lawrence E. 2000. Culture Matters: How Values Shape Human Progress. New York: Basic Books.

Kováts, András, ed. 2009. Bevándorló Budapest. [Migrant Budapest.] Budapest: Menedék.

Lewis, Richard. 2001. The Cultural Imperative: Global Trends in the 21st Century. Yarmouth, ME: Intercultural Press.

Mead, George. 1934. Mind, Self and Society. Chicago: University of Chicago Press.

S. Kriszt, Éva and Hidasi, Judit. 2010. "Chinese Presence in Hungary." In Chinatown and Beyond: Proceedings of 2009 International Conference (@ Vancouver: Simon Fraser University, 13-15 May 2009), ed. David C. Lam Institute for East-West Studies - Wing Lung Bank International Institute for Business Development - Hong Kong Baptist University - David See-Chai Lam Centre for International Communication Simon Fraser University, 52-62. HongKong: David C. Lam Institute for East-West Studies (LEWI) Wing Lung Bank International Institute for Business Development (IIBD) ILIJI David See-Chai Lam Centre for International Communication, Hong-Kong Baptist University. 